\title{
How effective is TPRS for adult EFL learners with limited English proficiency?
}

\author{
${ }^{\text {a}}$ Mehmet Asmalı \\ a Instructor, Alanya Alaaddin Keykubat University, Alanya, Antalya Turkey, asmalimehmet@gmail.com
}

To cite this article: Asmal1, M. (2019). How effective is TPRS for adult EFL learners with limited English proficiency? Focus on ELT Journal (FELT), 1(1), 86-95.

https://doi.org/10.14744/felt.2019.00005

\begin{abstract}
This study examines the impact of 'Teaching Proficiency through Reading and Storytelling' (TPRS) on students' grammar and vocabulary performance as well as their attitude toward learning English. The participants are 38 freshmen, 14 in experimental and 24 in control group, studying in the department of tourism and hospitality services of a 2-year vocational school at a state university in Turkey. A pre-test including grammar and vocabulary questions as well as an attitude questionnaire was used as pre-test and post-test in the beginning and end of a four-week intervention as the data gathering tool. TPRS technique was implemented for four sessions in the experimental group to teach target vocabulary and structures. While The Mann-Whitney U test was run to find out the differences between pre-test and post-test scores of control and experimental groups, Wilcoxon Signed Rank Test was employed to find out the differences between the pre-test and the post-test scores of experimental group. The results indicated that TPRS technique had positive impact on students' grammar and vocabulary performance as the students in the experimental group outperformed the ones in the control group in the posttest. TPRS technique was also found to be effective in creating positive attitudes toward learning English. Some implications to employ TPRS in English classes as well as suggestions for further research were also provided.
\end{abstract}

Keywords:

attitude toward language learning grammar 'Teaching Proficiency through Reading and Storytelling' vocabulary

\section{Introduction}

Finding an effective teaching method has always been a hard task for language teachers. 'Teaching Proficiency through Reading and Storytelling' (hereafter TPRS), once known as 'Total Physical Response Storytelling', has been one of the most popular recent attempts of the endeavor to find an effective language teaching method (Li, 2013). This technique was developed by a Spanish teacher Blaine Ray in California in 1990s to let the students master the basic vocabulary and structures of the target foreign language with the ultimate aim of fluency and accuracy in language learning (Ray \& Seely, 2012).

Considering these two elements of language learning, Turkish university students have had several problems. They consider themselves as unsuccessful in being accurate and fluent in learning English despite spending several years of study (Yurtsever Bodur \& Arıan, 2017). This failure stems from various reasons, such as inability of students' parents to 
speak English, lack of English programs on TV or radio, or lack of chance to go abroad to practice it (Yurtsever Bodur \& Arıkan, 2017). The students also criticize the fact that specifically speaking skill is mostly ignored in English classes (Yurtsever Bodur \& Arıkan, 2017).

Despite mostly attributing their failure in fluency and accuracy to external factors, Turkish university students predominantly have moderate or high motivation to learn English (Başaran \& Hayta, 2013; Bektaş Çetinkaya \& Oruç, 2010). Therefore, employing an intriguing method in foreign language teaching classes may be a step toward success of the learners. TPRS, which does not only focus on developing learners' fluency and accuracy through comprehensible and interesting stories, but also helps students to have more positive attitudes toward language learning (Türkeş, 2011). Although a consensus has not been reached among the scholars for TPRS method to be the best compared to other existing ones, a brief overview of the existing literature gives us insight that it increases the likelihood of having better results on several aspects, such as vocabulary acquisition (Kara \& Eveyik-Aydın, 2019; Türkeş, 2011), speaking skill (Muzammil \& Andy, 2017), listening (Susan, 2013), and lexical competence (Demir \& Cubukçu, 2014).

It cannot be claimed that this newly emerging technique has come to light suddenly and expanded rapidly. It has roots in universally accepted language teaching methods. Specifically, TPRS is based on the principles of Asher's Total Physical Response (hereafter TPR) and Krashen's Natural Approach (hereafter NA). Asher first demonstrated TPR in 1965 (Ray \& Seely, 2012). This approach as a method for language teaching predominantly focuses on developing learners' listening skill through modelling and uttering the commands which is followed by students' imitation of the action and repetition of the word (Harrasi, 2014). However, the effectiveness of TPR was highly controversial as there was a general consensus that all abstract ideas cannot be taught (Byram, 2004).

Although Blaine Ray had positive results with the use of TPR in his Spanish classes initially, students' motivation and willingness to attend the command-based activities showed a decrease (Ray \& Seely, 2012). In order to overcome this major challenge, Ray attempted to combine this method with NA through which language is aimed to be acquired subconsciously (Ray \& Seely, 2012). In this approach, learners learn second language as children learn their first language (Krashen \& Terrel, 1983). Five hypotheses of NA affected TPRS (Shrum \& Glisan, 2005). These are as follows:

- 'The acquisition-learning hypothesis' explains acquisition as the subconscious form of learning which allows learners to communicate spontaneously and creatively.

- 'The monitor hypothesis' states that with the acquisition of the language, students have oral production fluently and, at this point, learning monitors and corrects the production with the conscious learned rules of the language.

- 'The natural order hypothesis' claims that learners follow a predictable sequence of acquisition.

- 'The input hypothesis' states that learning occurs when the learners receive comprehensible input that is slightly beyond their level of comprehension. 
- 'The affective filter hypothesis' claims that learning can occur in a stress free atmosphere where learners' affective filter is low.

Both TPR and NA are acquisitionist approaches, in that they focus on meaning rather than form (Nunan, 2005). These two approaches have received considerable criticism with the changes in language teaching. As the educators' individual creativity and beliefs play a vital role in the development of classroom practice, varieties in individual practices exist and TPRS is one example of these varieties (Alley \& Overfield, 2008). Ray was satisfied with the results of neither TPR nor NA, hence he combined these two approaches and created a unique method (Ray \& Seely, 2012).

TPRS relies on the common and familiar communicative device of the story which is a way for the learners to engage with each other (De Costa, 2015). The input in TPRS technique should be 'comprehensible' to internalize the language, 'interesting' to expand the attention span of the learners, and 'repetitive' to help the retention of the structures (Ray \& Seely, 2012).

Taking its roots from these two approaches, The TPRS method has three main steps to follow in its unique way (Ray \& Seely, 2012):

'Establishing the meaning'- In this step, the new target vocabulary or structures are introduced to the learners through gestures, personalized questions, and translation. Translation helps learners to check the meaning if they forget. The teacher practices the structures and the vocabulary until the students become familiar with them (Ray \& Seely, 2012). One of the main aims of this step is to create a stress-free atmosphere where the learners would feel comfortable enough to respond the questions (De Costa, 2015).

'Asking the story'- Before starting this step, the teacher needs to be sure that all the structures and vocabulary have been written on the board or provided to the learners with the translations. In this step, the teacher creates a story or brings a story including the target structures and vocabulary that serves as a guide for that class. The stories are mostly bizarre and exaggerated (Alley \& Overfield, 2008). The story provides three locations. In the first location, a problem that could be solved is presented. In the second location, the character is not able to solve the problem. In this point, either the problem is changed or the information regarding why the problem cannot be solved is provided. Finally, the problem is solved in the last location (Ray \& Seely, 2012). Providing different locations helps students remember the details in the story. The teacher asks several different questions in this step, such as 'yes-no questions', 'either/or question', and 'wh question'. The teacher uses false statements to encourage engagement as well.

'Reading'- During this step, learners read and translate the story into their native language. With the younger learners, the teacher may ask the learners to draw the story as well.

During all these steps, the teacher needs to make it sure that all the students in the class, even the middle or low-performing ones in the 20th to 40th percentile, have comprehended the language used. The pace of the class could even be set according to these lower level students (Ray \& Seely, 1998). According to the criteria of the TPRS class, the input should 
be comprehensible, repetitive, and interesting which would help learners feel comfortable in the class so that they have more benefits with higher motivation, joy, and fun (Williyanti, 2008).

A brief overview of the related literature addressing the impact of TPRS on different language skills of the learners in the context of Turkey shows that the implementation of this method has been mostly preferred for younger learners. These recent studies have been conducted in the context of young learners in Turkey investigating whether TPRS should be employed with the young learners or not (Demir \& Cubukçu, 2014), the effect of TPRS on vocabulary acquisition (Çubukçu, 2014; Kara \& Eveyik-Aydın, 2019; Türkeş, 2011), and oral performance of the students (Y1ld1z Akyüz, 2018).

The effects of TPRS method have been examined in different contexts with the adult learners as well. Muzammil and Andy (2017) investigated TPRS in a quasi-experimental quantitative study using pre-test and post-test design with the freshmen at university in Indonesia in order to compare traditional method and TPRS in terms of developing speaking skills of the learners. They found out that the experimental group outperformed the control group in speaking performance. The results also indicated that while the implementation of the method made students happy, encouraged them to listen to partner's story and communicate using English in class, it was also a source for lecturers to make the class livelier to introduce new vocabulary.

In another study, Braunstein (2006) investigated adult Latino ESL learners' attitudes toward TPR and TPRS in class. The students received five-hour teaching combined of TPR and TPRS. Despite the students' expectations for more traditional approaches for language learning, they showed positive attitudes toward these two methods. They felt interested and happy in their TPRS classes. Specifically, about learning nouns and verbs, listening comprehension, and understanding the story when it is acted out impressed the learners.

The other study comparing the effectiveness of TPRS and Grammar Translation strategy in vocabulary acquisition among Hispanic adult ESL learners was conducted by Castro (2010). 25 participants took three classes. Pre-test and post-test comparison of the two techniques in vocabulary acquisition and retention showed that, contrary to other studies favoring TPRS, students who had Grammar Translation strategy outperformed the ones received TPRS training.

De Costa (2015) also investigated the effectiveness of TPRS and a method which does not include story context in a French immersion classroom. This quasi-experimental quantitative study using pre-test and post-test design measured French listening, vocabulary, culture, grammar, and writing improvements of the students in two groups. The results showed that in all aspects there was an improvement for both groups. However, although in vocabulary and culture there was not a statistically significant difference between the groups; in listening, grammar, and writing there was significant difference.

An overview of the existing literature shows that despite the abundancy of studies investigating TPRS from different perspectives, there has been a shortage on the studies examining TPRS with the adult learners in Turkish context. Moreover, the studies conducted with the young learners in Turkish context largely confined to vocabulary 
acquisition and oral performance of the students. The effect of TPRS on the other elements of language learning, such as grammar and listening have been neglected.

Therefore, this study addresses the following research questions:

- How does TPRS affect adult EFL learners' vocabulary acquisition and grammar performance?

- What are the experimental group students' attitudes toward the use of TPRS?

\section{Method}

\section{Setting and Participants}

The participants of the present experimental study were two classes of the department of tourism and hospitality services of a 2-year vocational school at a state university in Turkey. These two freshman intact classes were randomly assigned as 'control group' and 'experimental group'. The control group and the experimental group consisted of 24 (14 females and 10 males) and 14 ( 8 females and 6 males) participants respectively. The ages of the participants ranged from 19 to 24 .

The students of this department do not have a year-long-preparatory English language program before they start their first year. The students receive compulsory General English classes in the first year for four hours for 28 weeks with a total of 112 classes. The aim of the General English class is to let the students have elementary level English language skills.

\section{Design of the Study}

This experimental study was conducted in two intact classes that were regarded as control and experimental groups. A pre-test was administered in the beginning of the 4 -week treatment to both control and experimental groups. The pre-test, which was also used as post-test in this study, included 30 questions in total. The questions were prepared in line with the target structures and vocabulary included in 4 stories that served as a guide in TPRS classes. While the vocabulary section consisted of 20 questions, grammar section included 10 questions. Vocabulary and grammar sections included fill in the gaps and matching type questions. Students' attitude was also measured along with the pre-test through the use of attitude questionnaire including 10 items (Pae \& Shin, 2011). The attitude-related items used in the study of Pae and Shin (2011) were translated into Turkish and the internal consistency of the scale was $a=.90$.

The target vocabulary and structures aimed to be taught with TPRS method and distribution of them through the weeks are illustrated in Table 1 below: 
Table 1. The stories and the target vocabulary and structures

\begin{tabular}{lllll}
\hline & Week 1 & Week 2 & Week 3 & Week 4 \\
\hline Name of the story & Movie Star & Fat Man & Green Tea & Baseball Pig \\
$\begin{array}{l}\text { Target vocabulary } \\
\text { and structures }\end{array}$ & $\begin{array}{l}\text { Movie star, bump } \\
\text { into, delayed, } \\
\text { pissed off, } \\
\text { recognize, book, } \\
\text { boarding pass, } \\
\text { gate, catch your } \\
\text { flight, security }\end{array}$ & $\begin{array}{l}\text { Frustrated, } \\
\text { exhausted, give up, } \\
\text { date, make a } \\
\text { difference, really, } \\
\text { in fact, extremely, } \\
\text { thrilled }\end{array}$ & $\begin{array}{l}\text { Safe, first-class, } \\
\text { shop, get into, are } \\
\text { you crazy?, why } \\
\text { don't you..?, for } \\
\text { sure }\end{array}$ & $\begin{array}{l}\text { Direct flight, get a } \\
\text { grip, hire, raise, } \\
\text { reject, come on, } \\
\text { find out, big hitter, } \\
\text { home run, try out } \\
\text { for, impressed with }\end{array}$ \\
$\begin{array}{l}\text { Total number of } \\
\text { target structures } \\
\text { or vocabulary } \\
\begin{array}{l}\text { Total number of } \\
\text { words in the story }\end{array}\end{array}$ & 376 & 9 & 7 & 11 \\
\hline
\end{tabular}

The treatment was integrated into the regular English classes the students were receiving for four weeks. In each week, the students in the experimental group received three hours of TPRS technique. The learners in the control group learnt the same structures and the vocabulary following pre-reading, on reading, and post-reading activities.

The treatment in the experimental group, data collection and data analysis of the study were carried out by the researcher of the present study. The use of TPRS in this study followed the three main steps of this technique.

\section{Step 1: Establishing the meaning}

The target vocabulary and the structures were introduced to the students in the experimental group by writing them on the board and showing the pictures on the screen. The translations of them were also provided on the board. Following this, personalized questions were employed to help the learners internalize them. Some personalized questions were used in the classes, such as "who is your favorite movie star?" or "when are you frustrated?". The words and the structures were repeated several times in this step.

Step 2: Asking the story

The stories served as a guide in all four weeks. They included the target vocabulary and the structures. The stories involved bizarre information to take students' attention, such as 500 pounds as the man's weight or 85 cups of tea drunk by a frog every day. The stories were asked in three locations. In the first location, the problem was introduced (The fat man wants to lose weight, but he cannot). In the second location, the character tries to find a solution for the problem (he tries to go on a diet and do exercise). The third location offers a solution to the problem (he meets a girl and she cooks healthy food).

During this step, before moving to the question phase, the stories were listened three times in the class. Following listening, the teacher asked several questions to encourage the learners to speak, such as "is the man fat?", "does he want to lose weight or eat more?", 
and "what does he eat in his diet?". The details were asked repetitively. The students can also create a parallel story that resembles to the main story in this step.

Step 3: Reading

In this step, the students read the story along with the teacher. They translated the story into Turkish on a pair work. The volunteer students acted out the story to have fun in the class as well.

A post-test including the same questions with the pre-test as well as the attitude questionnaire used before the treatment were administered in both experimental and control groups at the end of the 4-week implementation of TPRS technique with the experimental group learners.

\section{Data Analysis}

As the participants in the groups were not randomly assigned to the groups and the sample size was small, non-parametric tests were employed in this study (Tailor, 2005). The Mann-Whitney $U$ test was run to find out the potential differences between pre-test and post-test scores of the control and experimental groups. Similarly, Wilcoxon Signed Rank Test was also conducted to find out the differences between the pre-test and the post-test scores of the experimental group.

\section{Results}

Firstly, in order to assess the knowledge of both control and experimental groups prior to the treatment in the experimental group, a pre-test, which was also used as the post-test, was administered. An attitude questionnaire added at the end of the pre-test was also conducted to check the current feelings of the students toward English language. The mean ranks of the groups and The Mann-Whitney U test results are presented below in Table 2.

Table 2. Pre-test results of the experimental and control groups

\begin{tabular}{llcccc}
\hline \multicolumn{1}{c}{ Tests } & Groups & Mean rank & Sum of ranks & U & p \\
\hline Pre-test (grammar) & Experimental & 18.57 & 260.0 & 155.000 & .692 \\
Pre-test (vocabulary) & Control & 20.04 & 481.0 & & \\
& Experimental & 18.64 & 261.0 & 156.000 & .723 \\
Attitude questionnaire & Control & 20.00 & 480.0 & & \\
& Experimental & 23.00 & 322.0 & 119.000 & .141 \\
& Control & 17.46 & 419.0 & & \\
\hline
\end{tabular}

The results concerning the differences between the control and the experimental groups showed that there was not a significant difference between these two groups in the pre-test $(\mathrm{U}=155.000, \mathrm{p}=.692$ for grammar; $\mathrm{U}=156.000, \mathrm{p}=.723$ for vocabulary; and $\mathrm{U}=$ $119.000, \mathrm{p}=.141$ for attitude questionnaire). Therefore, it could be claimed for both groups to have statistically equal knowledge regarding the target vocabulary and structures.

In order to assess the impact of TPRS on the students in the experimental group compared to the learners in the control group who were trained with the Communicative Approach as 
they were used to, The Mann-Whitney $U$ test was run one more time for the post-test scores after the treatment with the experimental group for four weeks. The results as presented in Table 3 above indicated statistically significant difference between the experimental group and the control group in terms of grammar $(U=48.000, p=.000)$, vocabulary $(\mathrm{U}=54.000, \mathrm{p}=.000)$, and their attitude toward learning English $(\mathrm{U}=3.000, \mathrm{p}$ $=.000)$.

Table 3. Post-test results of the experimental and control groups

\begin{tabular}{llcccc}
\hline Tests & Groups & Mean rank & Sum of ranks & U & p \\
\hline Post-test (grammar) & Experimental & 28.07 & 393.0 & 48.000 & .000 \\
& Control & 14.50 & 348.0 & & .000 \\
Post-test (vocabulary) & Experimental & 27.64 & 354.0 & 54.000 & \\
\multirow{2}{*}{ Attitude questionnaire } & Control & 14.75 & 387.0 & 3.000 & .000 \\
& Experimental & 31.29 & 438.0 & 303.0 & \\
\hline
\end{tabular}

As both groups were statistically equal in both vocabulary and grammar knowledge as well as their attitude toward English language learning in the beginning of the study as the pretest results indicated, Wilcoxon Signed Rank Test results comparing the potential differences between pre-test and post-test performances of the students in the experimental group showed significant changes. The implementation of TPRS in the experimental group for four sessions elicited significant change in grammar, $Z=-3.466, p=.001$, vocabulary performance $Z=-3.858, p=.000$, and their attitude toward learning English, $Z=-5.007, p$ $=.000$.

\section{Discussion and Conclusion}

The findings of this study supported the effectiveness of TPRS on the vocabulary and grammar performance as well as developing positive attitudes of elementary level adult EFL learners' toward learning English. Considering the existing literature in the context of adult learners, the results of this study regarding the impact of TPRS on learners' grammar performance are in line with those of De Costa (2015). Although his study was conducted in a French immersion classroom, the scores of the learners in the experimental group were statistically different from the ones in the control group as in the present study. His findings also indicated improvement in the vocabulary performance of the learners in the experimental group as well, but there was not a statistically significant difference between the groups which contradicts with the results of the current study concerning vocabulary acquisition.

Regarding the findings about learners' attitude toward learning English, the results of this study are in accordance with those of Braunstein (2006). The adult Latino ESL learners' attitudes were positive toward TPRS implementation in the class. The interest and happiness of the learners in Braunstein's study (2006) were also observed in the experimental group learners in the present study. Specifically, personalization, which is provided through the personalized questions during 'establishing the meaning' step of TPRS, helps learners to establish interest, curiosity, and stimulation (Ray \& Seely, 2012). The comprehensible input that the students receive through the stories and the questions 
are considered interesting by the learners and their positive attitude toward the class becomes immediately apparent. As the TPRS method is based on the use of stories in EFL classes to develop fluency with the help of grammar structures and vocabulary learnt by getting exposed to comprehensible, repetitive, and interesting input, the learners in TPRS classes have fun and learn in a natural and inductive way (Ray \& Seely, 2004).

Therefore, as it is presented in the literature section above, the studies addressing the issue of the impact of TPRS on several language skills and the attitudes of the learners presented mostly positive results as in this study. Considering the results of this study as well as the ones in the literature, TPRS method may be used in EFL classes with the learners who perform poorly due to their limited English proficiency to let them fully engage with the topic and enhance their learning. As it is an intriguing method, it may also be employed with the learners who are not much interested in English classes to develop their performance by eliminating the distractors and to let them focus on the story.

Some limitations of the current study need to be addressed in further research. To start with, both groups in this study were intact classes. Although not typical of experimental research, these classes may have the advantage of enhancing face validity, but at the same time, as it is universally accepted, randomization enhances the experimental validity of the study (Mackey \& Gass, 2005). Hence, further research may involve randomly assigned groups with larger samples to assess the impact of TPRS on adult learners' language learning with a higher experimental validity. A delayed-post-test may be employed to examine the longitudinal effect of TPRS on different skills. Moreover, instructors' views through interviews and students' ideas through journals may provide significant results for the researchers.

\section{Disclosure Statement}

No potential conflict of interest was reported by the authors.

\section{References}

Alley, D., \& Overfield, D. (2008). An analysis of the teaching proficiency through reading and storytelling (TPRS) method. In Cherry, C, \& Wilkerson, C. (2008). Languages for the nation, Selected Proceedings of the 2008 Joint Conference of the Southern Conference on Language Teaching (pp. 1327). Retrieved from: https://files.eric.ed.gov/fulltext/ED503097.pdf

Başaran, S., \& Hayta, F. (2013). A correlational study of Turkish university students' motivation to learn English. Electronic Journal of Education Sciences, 2(3), 104-115. Retrieved from https://dergipark.org.tr/tr/pub/ejedus/issue/15937/167582

Bektaş Çetinkaya, Y., \& Oruç, N. (2010). Turkish students` motivation to learn English at public and private universities. Procedia Social and Behavioral Sciences. 2, 4662-4666. doi: 10.1016/j.sbspro.2010.03.746

Braunstein, L. (2006). Adult ESL learners' attitudes toward movement (TPR) and drama (TPR storytelling) in the classroom. The CATESOL Journal, 18(1), 7-20. Retrieved from http://www.catesoljournal.org/wp-content/uploads/2014/07/CJ18_braunstein-1.pdf

Byram, M. (2004). Routledge encyclopedia of language teaching and learning. London: Routledge.

Castro, R. (2010). A pilot study comparing total physical response storytelling ${ }^{\mathrm{TM}}$ with the grammartranslation teaching strategy to determine their effectiveness in vocabulary acquisition among English as a second language adult learners (Unpublished master's thesis). Dominican University of California, San Rafael, CA. doi: 10.33015/dominican.edu/2010.edu.08

Demir, Ş., \& Cubukçu, F. (2014). To have or not to have TPRS for preschoolers. Asian Journal of instruction, 2(1), 186-197. Retrieved from https://dergipark.org.tr/tr/download/article-file/17655 
De Costa, R. M. (2015). Traditional methods versus TPRS: Effects on introductory French students at a medium-sized public university in the Midwestern United States (Unpublished master's thesis). Minnesota State University, Mankato, Minnesota. Retrieved from: https://cornerstone.lib.mnsu.edu/cgi/viewcontent.cgi?article $=1512 \&$ context $=$ etds

Çubukçu, F. (2014). Synergy between storytelling and vocabulary teaching through TPRS. ELT Research Journal, 3(2), 84-90. Retrieved from https://dergipark.org.tr/tr/download/article-file/63639

Harrasi, K. T. S. A. (2014). Using "Total Physical Response" with young learners in Oman. Childhood Education, 90(1), 36-42, doi: 10.1080/00094056.2014.872513

Kara, K., \& Eveyik-Aydın, E. (2019). Effects of TPRS on very young learners' vocabulary acquisition. Advances in Language and Literary Studies, 10(1), 135-146. doi: 10.7575/aiac.alls.v.10n.1p.135

Krashen, S. D., \& Terrell, T. D. (1983). The natural approach: Language acquisition in the classroom. Hayward, CA: Alemany Press.

Li, N. (2013). Is TPRS an effective method for teaching Chinese as a foreign language among young learners of beginning levels? In The European Conference on Education Official Conference Proceedings (pp. 639-650). Retrieved from http://papers.iafor.org/wp-content/uploads/conferenceproceedings/ECE/ECE2013_proceedings.pdf

Mackey, A. \& Gass, S. M. (2005). Second language research methodology and design. London: Lawrence Erlbaum Associates.

Muzammil, L., \& Andy (2017). Teaching proficiency through reading and storytelling (TPRS) as a technique to foster students' speaking skill. Journal of English Education and Linguistics Studies, 4(1), 19-36. Retrieved from https://jurnal.iainkediri.ac.id/index.php/jeels/article/view/329/238

Nunan, D. (2005). Classroom research. In E. Hinkel (Ed.), Handbook of research in second language teaching and learning (pp. 225-240). Mahwah, NJ: Lawrence Erlbaum.

Pae, T., \& Shin, S. K. (2011). Examining the effects of differential instructional methods on the model of foreign language achievement. Learning and Individual Differences, 21, 215-222. doi: 10.1016/j.lindif.2010.11.023

Ray, B., \& Seely, C. (1998). Fluency through TPR storytelling. Berkeley, CA: Command Performance Language Institute.

Ray, B., \& Seely, C. (2004). Fluency through TPR storytelling (4 ${ }^{\text {th }}$ ed.). Bakerfield, CA: Command Performance Language Institute.

Ray, B., \& Seely, C. (2012). Fluency through TPR storytelling: Achieving real language acquisition in school. Berkley: Command Performance Language Institute.

Shrum, J. L., \& Glisan, E. (2005). Teacher's handbook: Contextualized language instruction ( ${ }^{\text {rd }}$ ed.). Boston: Thomson Heinle.

Susan, I. (2013). The use of teaching proficiency through reading and storytelling (TPRS) to improve students` listening comprehension. Journal of English and Education, 1(1), 104-113. doi: https://ejournal.upi.edu/index.php/L-E/article/view/335

Tailor, G. R. (2005). Integrating quantitative and qualitative methods in research, $2^{\text {nd }}$ edition. Oxford: University Press of America.

Türkeş, D. (2011). The role of TPRS method in teaching vocabulary to the $5^{\text {th }}$ grade primary EFL students (Unpublished master's thesis). Çukurova University, Adana, Turkey. Retrieved from: http://libratez.cu.edu.tr/tezler/8646.pdf

Williyanti. (2008). The effectiveness of Total Physical Response Storytelling in improving the students listening comprehension. Bandung: Unpublished paper.

Y1ldız Akyüz, G. (2018). The effect of teaching proficiency through reading and storytelling (TPRS) method on the oral performance of young learners (Unpublished master's thesis). Balıkesir University, Balıkesir, Turkey.

Yurtsever Bodur, G., \& Arıkan, A., (2017). Why can't we learn English?: Students' opinions at Akdeniz University. Gaziantep University Journal of Educational Sciences, 1(1), 1-7. Retrieved from https://dergipark.org.tr/tr/pub/http-dergipark-gov-tr-journal-1517-dashboard/issue/31230/341795

\section{Copyrights}

Copyright for this article is retained by the author(s), with first publication rights granted to the Journal.

This is an open-access article distributed under the terms and conditions of the Creative Commons Attribution license (CC BY-NC-ND) (http://creativecommons.org/licenses/by-nc-nd/4.0/). 